\title{
Introduction: Changing tourism in the cities of post-communist Central and Eastern Europe
}

\author{
Duncan Light*, Remus Creţan ${ }^{* *}$, Sorina Voiculescu** and loan Sebastian Jucu****
}

*Bournemouth University, Department of Tourism and Hospitality, Fern Barrow, Poole, Dorset, UK, BH12 5BB. e-mail: dlight@bournemouth.ac.uk

**West University of Timişoara, Department of Geography, Bd Vasile Parvan 4 Timişoara 300233, Romania e-mail: remus.cretan@e-uvt.ro

***West University of Timişoara, Department of Geography, Bd Vasile Parvan 4 Timişoara 300233, Romania, e-mail: sorina.voiculescu@e-uvt.ro

****West University of Timişoara, Department of Geography, Bd Vasile Parvan 4 Timişoara 300233, Romania, e-mail: ioan.jucu@e-uvt.ro

Corresponding author. Remus Cretan, West University of Timişoara, Department of Geography, Bd Vasile Parvan 4 Timisoara 300233, e-mail: remus.cretan@e-uvt.ro

${ }^{*}$ All authors contributed equally to writing this article

\section{Abstract:}

This special edition examines various aspects of urban tourism in the post-communist cities of Central and Eastern Europe (CEE). It begins by examining the nature of tourism restructuring in the region since the end of communism and the way that this unfolds in cities. It then examines major global changes in the nature of tourism and their impacts on urban tourism in CEE. These include the growing demand among tourists for new experiences and destinations; the impact of budget airlines on tourism in smaller cities; the impacts of the sharing economy (particularly Airbnb); and the growing emphasis on events and festivals as a means of attracting visitors to cities. The article ends by introducing the six articles that make up this special edition.

Key-words: urban tourism, post-communism, Central/Eastern Europe, events

\section{Urban Change in Post-Communist Central and Eastern Europe}

When communist regimes came to power throughout Central and Eastern Europe (CEE) after the Second World War the implications for cities were profound. Cities were central to the communist project, being the central focus of efforts to introduce a planned economy and classless society. ${ }^{1}$ Cities were planned as centres for industry (a key dimension of the modernisation that was central to communism) and people. As a result, cities industrialised rapidly during the communism era, which was accompanied by the large-scale construction of new residential districts for the workers. In spatial terms, priority was given to the industrial and residential districts, and city centres were relatively neglected. Capital cities enjoyed a particular importance as symbolic expressions of state power, ${ }^{2}$ which resulted in the 
construction of monumental buildings, a concentration of monuments and statues, and the creation of new open spaces for mass gatherings.

Cities in CEE have faced radical challenges in the post-communist period. Internal restructuring and the dismantling of the centrally-planned economy has led to the decline, privatisation (and closure) of many communist-era factories. Not only has this created a problem of urban dereliction and new brownfield sites, ${ }^{3}$ but many urban authorities have also had to deal with high rates of unemployment. At the same time, post-communist cities have been exposed to the forces of globalisation and neoliberalisation. This requires them to be competitive and entrepreneurial ${ }^{4}$ within the international and regional economy in order to attract foreign direct investment ${ }^{5}$ and bring new jobs to the city. Cities have also been required to create new post-socialist urban identities as appealing places to visit and in which to do business. Successful cities have also experienced new pressures with internal migration driven by a search for employment which, in many cases, has created or exacerbated housing shortages. Thus, post-communist cities are characterised by uneven development and growing social inequalities which contrast sharply with the nature of urbanisation under communism.

The form and appearance of cities has also changed since the collapse of communist regimes. The communist-era urban planning system has been dismantled and replaced by a less coordinated and less integrated form of urban management. This has allowed rapid and uncoordinated suburbanisation on the margins of the communist city led by emerging wealthy elites, along with increased urbanisation of the rural hinterlands of these cities. At the same time, the inner city has been revived through gentrification, ${ }^{6}$ in which the requirement for city-centre office space among the rapidly-expanding business sector has been a key driver. International investors have constructed new office complexes, bringing a new form of steel and glass architecture to the city centre. Furthermore, entire new business districts have emerged, now dominated by the service sector. The monumental buildings and commemorative spaces in city centres which formerly served the communist ideology are now redundant and have been reconfigured and put to new uses as part of the broader process of remaking national identity. ${ }^{7}$

\section{Urban Tourism in Central and Eastern Europe}

Tourism in the cities of CEE is not a recent phenomenon: before the Second World War many of the historic towns and cities of Central Europe (particularly spa resorts) were popular destinations, albeit among a social elite. ${ }^{8}$ Such tourism continued when communist regimes assumed power throughout the region, although it was now confined to domestic tourists. However, from the 1960s onwards most states in the region liberalised access for visitors from non-socialist countries and in this context some cities and towns (particularly the capitals of Prague, Budapest and East Berlin) became destinations for visitors from nonsocialist countries (although the number of such visitors was always low). This situation changed dramatically following the collapse of communist regimes when some of the formerly communist states experienced a dramatic increase in tourist arrivals. ${ }^{9}$ Many of these tourists were motivated by curiosity to see the countries which had formerly been behind the 'Iron Curtain' and took advantage of the new ease of access. Much of this tourism was concentrated in urban areas, with particular cities - especially Prague and Budapest - 
witnessing large increases in visitor numbers. The post-communist period also saw a significant increase in business travel to the region's cities.

Since then, the volume of international and domestic tourism has expanded considerably in CEE. Between 1990 and 2018 international tourist arrivals in the region grew from 33.9 million to 141.4 million (an increase of $317 \%$ ) while in 2018 international tourism generated $€ 58$ billion in receipts. ${ }^{10}$ The accession of 10 former communist countries to the European Union (EU) in 2004 and 2007 further stimulated international tourist interest in these countries. ${ }^{11}$ Tourist growth is forecast to continue and prior to the COVID-19 pandemix of 2020 international arrivals were expected to reach 176 million by $2030 .{ }^{12}$ Much of the increase in visitor arrivals has been concentrated in cities and towns within the region. The showpiece heritage cities of the region have seen persistent increases in visitor arrivals. For example, between 2003 and 2011 the number of tourists visiting Prague increased by $70 \%$, while Budapest experienced a $40 \%$ increase. ${ }^{13}$ Indeed, the most popular cities (such as Prague) increasingly face the challenges of overtourism. However, smaller cities have similarly recorded big increases in tourist arrivals. For example arrivals in Leipzig (former East Germany) increased by $147 \%$ between 1992 and $2000^{14}$, while the number of staying overnight visitors to Łódź (Poland) increased by $125 \%$ between 1990 and $2010 .{ }^{15}$

The post-communist period has been characterised by radical restructuring of the tourism industry inherited from communism, and much of this has played out in urban areas. The most obvious instance is the restructuring of the accommodation sector. Urban hotels were almost entirely state-owned during the communist era, and in the early 1990 s many were under-capitalised and in need of refurbishment. ${ }^{16}$ The urban accommodation stock was largely privatised in the first post-communist decade, through a variety of methods. ${ }^{17}$ Some were sold to their employees, but in many cases international hotel chains have purchased existing buildings and refurbished them. For a considerable time there was an underprovision of accommodation for tourists in many cities. For example, in the early 1990s Warsaw could offer only 6000 rooms for tourists. ${ }^{18}$ To provide additional capacity, many international chains also constructed new hotels, both in capital cities and in smaller cities and towns. However, in many countries this process was delayed by uncertainty over land and property ownership and complex administrative and bureaucratic hurdles posed by the administrative systems of the communist era. ${ }^{19}$ Private sector investors (both domestic and foreign) have also funded the refurbishment and upgrade of city centre properties, which subsequently opened as new hotels, hostels and holiday apartments. Thus, tourism is an additional vector of gentrification in city centres. More recently some cities have reached a state of over-supply of accommodation: in both Prague and Budapest bed occupancy rates have fallen below $50 \% .^{20}$

During the communist era tourism, like other economic sectors, was carefully regulated by the state authorities. In the post-communist period the intervention of the central state was substantially relaxed ${ }^{21}$, being largely confined to the production of national plans, policies and promotional strategies. Tourism development was, therefore, largely left to the rapidly expanding private sector. However, at the local level many urban administrations have becoming increasingly involved with tourism planning and promotion. In many towns and cities, internal economic restructuring along with increased exposure to the competitive global economy resulted in the bankruptcy and closure of former state-owned enterprises such as factories. ${ }^{22}$ Faced with the need to secure employment for the local populace, many 
cities have recognised the contribution that tourism can make to local economic development so that the promotion of tourism has become a common element of local development strategies. As a result, cities have embraced place marketing and branding ${ }^{23}$ in order to promote themselves as tourist destinations and enhance their competitive position. Here it is important to note that these trends - the need to be competitive through an increasing reliance on the service sector - are not unique to post-communist cities but instead mirror the neoliberalisation of cities more broadly throughout the world.

\section{Global Changes in Tourism and their influences on Cities}

In addition to the influences of internal economic and political restructuring, tourism in the cities and towns of Central and Eastern Europe is also being shaped by global changes in the nature of tourism. Foremost among these is the increasing desire among tourists for new and unusual experiences and destinations. Over the past three decades there has been an increasing reaction against the standardised experiences and destinations of mass tourism which has led many (predominantly middle-class) tourists to look for different forms of holiday. Furthermore, contemporary consumers are characterised by a continual demand for novelty, innovation and freshness, and these desires extend to their practices of holidaymaking. ${ }^{24}$ The result has been a proliferation of niche forms of tourism, catering for customers with specific interests and requirements. This has led to the emergence of a 'new' (or 'post-mass') type of tourist who are "increasingly sophisticated in their needs and preferences, and similarly adept in ensuring that their needs are met". ${ }^{25}$ They search for novel and unusual experiences in new (and relatively less popular) destinations. Globally, the tourist industry has responded by developing and promoting new forms of tourist experiences, in new places, intended for this new form of demand.

The cities of post-communist Central and Eastern Europe have much to offer to these 'new' tourists, in the forms of new products, new experiences, and new destinations. In particular, these cities have a rich offer for heritage tourism (the largest segment of 'new' tourism). The region's capital cities (Prague, Budapest, and later Bratislava, Ljubljana, Riga, Tallinn and Vilnius) were popular early destinations, but over time second-tier cities and regional centres (such as Brno, Debrecen, Krakow, Plovdiv, Sibiu, St Petersburg, Split, Tartu, Kaunas and Lviv) have also become established centres for heritage tourism. ${ }^{26}$ Indeed, many cities have mobilised heritage and culture in their place promotion and marketing, seeking to create place identities which are characterised by a shared architectural cultural heritage with Central and Western Europe. In so doing they are projecting a message that they are 'normal' places to visit and do business in. ${ }^{27}$

The popularity of heritage tourism has also had direct consequences for the historic towns and cities in Central and Eastern Europe. Communist regimes largely neglected historic city centres, partly because, as expressions of individual wealth they were antithetical to the socialist project, ${ }^{28}$ but also because priority was given to constructing new housing and industrial centres on the margins of existing urban areas. As a result the historic cores were simply neglected and left to deteriorate. ${ }^{29}$ In the post-communist period many countries have invested in the refurbishment and regeneration of the historic centres of their capital cities with the intent of creating a showpiece heritage city that symbolises their new, postindependence political identity. In smaller cities and towns, local administrations have also 
funded and supported the regeneration of historic centres to increase their attractiveness to tourists. Furthermore, many private owners who lacked the capital to refurbish their citycentre properties have sold them to domestic and foreign investors who have converted them into hotels, bars and restaurants intended for tourists. All this means that the character of historic city centres has changed substantially: whilst under communism they were primarily residential in nature, such areas are now dominated by commercial activities, along with high-end residential accommodation. ${ }^{30}$ Post-communist historic city centres are increasingly places for the wealthy, and in some cases, historic city centres are close to becoming tourist enclaves. ${ }^{31}$

The cities of Central and Eastern Europe also offer unique historic resources which appeal to tourists in search of the new and unusual. One example is the heritage of communism itself, in the form of monumental public buildings, monuments and statuary, working-class housing districts, along with recently developed museums which present and interpret the communist past. While such 'communist heritage' ${ }^{32}$ is little valued by local populations, it is increasingly attractive to visitors to the region and is consequently commodified and sold in a form which is easily accessible to foreign tourists. Examples include walking tours of the remains of the Berlin Wall; Bucharest's monumental 'House of the People' (now the city's most-visited attraction); Budapest's 'Statue Park'; and the 'Crazy Tours' of Nova Huta (a communist-era housing estate in Krakow) in an East German Trabant car. Another unusual heritage in the countries of the former Yugoslavia is the legacy of the conflict of the early 1990s. Thus, in Bosnia and Hercegovina a tunnel in Sarajevo which was used during the conflict to enable people, food and humanitarian aid to move in and out of the city has now been turned into a museum. Elsewhere in the country a $16^{\text {th }}$ century bridge in Mostar (which was shelled during the conflict) has been rebuilt and is now a popular tourist site.

Other unique forms of heritage are more intangible in nature. The cities of Central and Eastern Europe offer a diverse range of national and local specialities in terms of food and drink, and these are increasingly attractive to tourists who seek new places and experiences. Indeed, 'gastronomy tourism' (also known as culinary tourism or food tourism) - where tourists travel to a destination specifically to experience local food and drink - is an increasingly important form of special interest tourism. ${ }^{33}$ Such tourism is increasingly popular in the cities of Central and Eastern Europe, and many are actively promoting food and drink as part of their tourist product. Indeed, given the close relationship between food and place identity, local food and drink specialisms are widely used within place promotion strategies in order to underline place distinctiveness and ensure competitive advantage. ${ }^{34}$ Furthermore, private sector providers have enthusiastically developed packages themed around local cuisine.

However, some tourists in search of the new and unusual may prefer to focus on the contemporary city, rather than its heritage. The cities of Central and Eastern Europe are increasingly popular for 'off the beaten track tourism'35 in which visitors seek to move beyond a city's established tourist attractions in the city centre and search instead for authentic experiences of the city through independent exploration and sightseeing in what MacCannell ${ }^{36}$ has described as the 'back region' of a destination. This 'new urban tourism' is about an encounter with the ordinary and with the everyday life of the city's inhabitants. ${ }^{37}$ It is particularly centred in working class districts and former industrial areas, such as the Nova Huta housing district of Krakow and the Kreuzberg district of Berlin. Such practices overlap 
with 'slow tourism'38 in which a visitor seeks to take their time and 'connect' to a place (and indeed some cities are seeking to promote 'slow quarters' within the city). ${ }^{39}$ Another related issue is creativity and creative tourism. ${ }^{40} \mathrm{New}$ urban tourists are drawn to the edginess and buzz of creative districts (characterised by a vibrant contemporary arts scene) and creative districts are increasingly popular for tourists in cities such as Berlin, Krakow, Tartu, Kaunas, Wroclav and Leipzig.

A second trend which is having a major impact on tourism in the cities of Central and Eastern Europe is the huge increase in air transport connections, driven by the rise of low cost carriers. These companies work on a 'no frills' business model, allowing them to offer cheaper flights to customers. Within the European Union, the progressive liberalisation of air transport has enabled airlines with a license to operate within a member country to start business in another country (which, after the EU enlargements of 2004 and 2007, included the former communist states of Central and Eastern Europe). Furthermore, many new low cost carriers were established within the CEE countries themselves and they quickly introduced new routes. The result was a dramatic increase in point-to-point connections within Europe, with a particular growth of new routes to smaller/regional airports which offered cheaper landing fees. ${ }^{41}$ By 2008 the number of connections between 'Western' Europe and Central/Eastern Europe had reached 500 with $57 \%$ of the seats on these new routes being offered by low cost carriers. ${ }^{42}$

The growth of new airline connections to the cities of Central and Eastern Europe has had many implications. In particular, new accessibility has been a major stimulus to tourism development in many the smaller cities (such as Gdansk, Kosice, Timişoara, Debrecen, Burgas, Kaunas, Tuzla and Ohrid). Such cities are ideally placed to cater for the desire (identified above) of contemporary tourists to seek out new and 'undiscovered' destinations. More broadly, new air connections have been a major stimulus to local and regional development around airports. ${ }^{43}$ However, low cost air connections have also had unforeseen consequences, one of which is the growing popularity of some historic cities as destinations for 'stag party tourism'. Such tourism is driven by young people (known as Millennials or Generation Y). This group values exciting and memorable experiences; enjoys socialising with people of their own age; is always looking out for something new; is highly price conscious; and relies on social media and the opinions of their peers to find out about new places to visit. ${ }^{44}$ The easy accessibility and availability of cheap accommodation and alcohol means that a number of cities (particularly Prague, Bratislava, Krakow, and Tallinn) have become established destinations for stag party tourism. ${ }^{45}$ Such tourism has led to conflict between hosts and visitors, with some cities now trying to discourage it. More broadly, Millenials are looking for new cities with a vibrant nightlife, and make use of social media to find out about such places. Consequently a number of cities (including Zagreb, Belgrade, Warsaw, Poznan, Cluj, Kiev, Dubrovnik and Vilnius) in Central/Eastern Europe with a domestic reputation for exciting nightlife are increasingly attracting foreign Millenial tourists who are drawn to the night time economy. The result is that some places are gaining a European reputation as 'party cities'. Once again, this sort of tourism is facilitated by low cost airlines.

A third trend which is having a major influence in the cities of Central and Eastern Europe is the rise of the 'sharing economy'. A major influence has been the rise of AirBnB, a peer-topeer platform which allows the residents of a city to offer accommodation (which can range 
from a spare bedroom to an entire apartment) at a price of their choice to visitors. Both hosts and users pay a fee for this service, and in order to maintain a reputation for trustworthiness both hosts and guests can provide online feedback on each other. ${ }^{46}$ The impacts of Airbnb are significant: it is an additional source of income for citizens (enabling new forms of entrepreneurship for those who might otherwise have limited opportunities to set up their own businesses), while consumers benefit from increased provision of accommodation and lower prices. ${ }^{47}$ This in turn can potentially enable greater numbers of people to visit a city, including those who may not otherwise have been able to afford to stay in existing hotels. Airbnb is rapidly increasing its presence in Central and Eastern Europe: in 2017 there were around 12,000 offers of accommodation in Berlin, 9250 in Budapest and 4497 (providing 15,861 bedspaces) in Warsaw. ${ }^{48}$

The impacts of Airbnb are significant. In some cases, the sharing economy can compensate for an under-supply of tourist accommodation in a city, particular where that city is rapidly increasing in popularity as a destination. Airbnb can also increase accommodation provision outside the city centre ${ }^{49}$ and as such its offer is appealing to new urban tourists who are seeking more immersive experiences of the city. However, in other cases Airbnb can pose a significant challenge to existing hotels and other accommodation providers. Furthermore, the accommodation provided may not comply with health/safety regulations for tourist accommodation, while the revenues generated by providers may not be declared to the taxation authorities, thereby reducing a city's taxable income from tourism. Perhaps most importantly, accommodation provided through the sharing economy may remove apartments from the domestic rental market, thereby exacerbating existing housing problems and social inequalities. ${ }^{50}$ Therefore, although Airbnb is largely unregulated, some cities - most notably, Berlin - have banned the rental of entire apartments through sites like Airbnb. There is little doubt that the sharing economy will continue to be a significant influence on the cities of Central and Eastern Europe although the ways in which this will unfold have yet to become fully clear.

The fourth trend that is increasingly influential in the cities of CEE is a growing emphasis on events and festivals as a means of attracting visitors. Events are a temporary collection of cultural activities based on a particular theme. They are an addition to a city's tourist product intended to attract new visitors, and raise its profile as a place to visit. Events are widely used within broader tourism strategies intended to bring about urban regeneration. ${ }^{51}$ More broadly, they are an increasingly important component of neoliberal urbanism in which cities are striving to increase their competitiveness and establish distinct brands as destinations to visit and in which to do business.

Urban events and festivals have a long tradition in the cities of Central and Eastern Europe,$^{52}$ and were well-established during the communist era (although they were largely intended for domestic audiences). However, they have assumed much greater importance over the past decade. Some events are international in nature and cities can compete with one another to host them. Examples include the Football World Cup (hosted by Russia in 2018), the Winter Olympic Games (also hosted by Russia in 2014) and the UEFA Football Championship (hosted jointly by Poland and Ukraine in 2012). Others take place annually, the best known being European Capital of Culture $(\mathrm{ECOC})$ which has been hosted by various cities in the formerly communist part of Europe including Weimar (1999), Krakow and Prague (2000), Sibiu (2007), Vilnius (2009), Tallinn (2011), Maribor (2012), Košice (2013), 
Riga (2014), Plzeň (2015), Wrocław (2016) and Plovdiv (2019). Other events and festivals are initiated by cities and towns at a regional or local level, aimed at a wide range of target audiences of different ages. Some charge a fee for entrance, while others are free to all. They include festivals themed around music (whether jazz, classical music, or rock), art, theatre, film, literature, dance, and food/drink. Other events include air shows and car shows. Every post-communist city that is serious about attracting visitors now offers a yearlong programme of events and festivals, in an effort to attract new visitors, extend the tourist season, and contribute to broader economic development and regeneration.

\section{The Articles in this Special Edition}

The articles in this special edition explore a number of aspects of urban change in the contemporary cities of Central and Eastern Europe. The first article by Raularian Rusu, Voicu Bodocan and Titus Man examines the impacts of unplanned suburban sprawl - a very commonplace phenomenon in the cities of the region - on urban tourism. With reference to the city of Cluj-Napoca the authors chart how urban sprawl has created a strong of 'placeless' suburbs in the city but, at the same time, has led to a significant rise in new accommodation units situated in the peripheral areas of the city. This in turn has led to the development of new 'resorts' on the city's margins which are increasingly popular destinations among the city's residents for weekend tourism. In addition to reshaping the tourism geography of Cluj these developments have had unexpected impacts on the centre of the city where traffic congestion has been reduced.

The second article of this special issue examines the role of 'mega events' - specifically, European Capital of Culture - within post-communist cities. Florentina Popescu and Sorina Voiculescu focus on the Romanian city of Timişoara which is preparing to host ECoC in 2021. In particular they focus on place-making - seen as an interface between institutions, policies, and public/private property - in the run up to the Capital of Culture event. They argue that while the city is experiencing a marked growth in international visitors (particularly business/conference tourism) the local authorities face significant challenges in preparing for the expected influx of tourists in 2021. In particular, there is a need for greater coherence in policy, and stronger communication between the local authorities, other stakeholders and the local community if the event is to be staged successfully. The authors argue that what is needed is for the local authorities to put in a place a new tourist culture that promotes inclusive tourism during the events of 2021.

Ilie Rădoi also focuses on European Capital of Culture in Timişoara but takes a broader perspective looking at the role of cross-border cooperation with the Serbian city of Novi Sad which will also host European Capital of Culture in 2021. This is the first occasion in the history of ECoC that two cities from neighbouring countries will host the event. Current European Union policy is to reshape borders from being barriers between countries to being bridges of cooperation which can create stronger ties between communities. Accordingly ECoC presents an important opportunity for Timişoara and Novi Sad to jointly shape regional cooperation. Therefore urban tourism has a key role as a catalyst for cross-border collaboration and has the potential to enhance regional development and integration. Rădoi examines the possibilities and challenges of using ECoC for regional place-making in two cities in neighbouring states that have long-standing historical and geographical connections. 
Two further articles focus on the importance of other forms of cultural events, again illustrating the importance of events and festivals for post-communist cities. Ioan Sebastian Jucu analyses the rebranding of the cultural legacy of communism with reference to the 'Golden Stag' (Cerbul de Aur) Festival in the Romanian city of Braşov. Originally established in 1968, the festival was rebranded in the post-communist period and became an important expression of national and local identity, as well as having a role to play in post-communist place-making within the city. However, the Golden Stage festival failed to win financial support from the local authority or private sponsors and the final edition was held in 2009, although it was revived in 2018. On one level, the article illustrates that festivals are not a guaranteed route to urban renewal, but it also points to the importance of a festival that is distinctive in terms of form and content (in order to compete with other festivals such as Cluj's "Untold" - see below) and the need to have the support of local people, policy-makers and other stakeholders.

Iulia Ciangă also examines the relationship between festivals, creativity, place-making and local economic development. She does so with reference to the 'Untold Festival', an electronic music festival held annually in the city of Cluj, Romania. Since its first 'chapter' in 2015 Untold has enjoyed extraordinary success in a short space of time, attracting major international performers and drawing visitors from throughout Europe. Beyond popularizing local urban culture the festival promotes Transylvania's myths, and Romanian culture and traditions. It has made a major contribution to the visitor economy of the city and a broader contribution to economic development in the region. Ciangă reports a survey with the festival's participants whose results rest on two issues: the marketing campaign focused on promoting the image of Transylvania is considered innovative, while the diverse participants (Romanian, British, Germans etc) are open not only to be present at the festival but are also interested to explore the landmarks of the region and the local traditions. The article argues that the festival has an important contribution to enhance the touristic profile of Cluj-Napoca, Transylvania and in the long run that of Romania.

Finally, Liliana Popescu, Amalia Bădiţă and Costela lordache focus on the role of cultural heritage in urban place-making and regeneration. Like many other cities in the region, Craiova in Romania is seeking to valorise local heritage to create a distinct urban brand and increase the attractiveness of the area for the local community, visitors, and potential investors. This is one example of how a city can seek to establish itself as a destination for those tourists who are looking for new places to visit. The city authority initiated a project to produce an interpretation strategy for the city. This involved engaging local people about what heritage should be valorised and which stories should be told about the city. Such a 'bottom-up' initiative is intended to enhance awareness, understanding, appreciation and civic engagement among the urban population. The authors argue that understanding the perspectives of local residents in this way is important for establishing a clear place identity for the city and enhancing its competitiveness as a destination.

A short collection of articles such as this cannot illustrate the myriad ways in which tourism has shaped - and continues to shape - the cities of post-communist CEE. Nevertheless, the 6 articles in this special edition illustrate many of the most important themes and issues for urban tourism in the region. First, they demonstrate the impacts of tourists upon the cities of the region. These impacts are mainly economic (particularly the contribution of tourism to 
local economic development) but also the role of tourism in reshaping the physical fabric and public space of the city itself. Second, they demonstrate how important it is for cities to offer their visitors novelty and stimulation, particularly through temporary phenomena such as events (whether the year-long $\mathrm{ECoC}$ ) or the week-long Untold festival) in order to remain competitive as destinations. Third, they demonstrate the importance of local planning for tourism, and the need for the local authority to play a increasingly interventionist role in the development and implementation of tourism policy and planning. Fourth, they underline the importance of place in the development of tourist products, and the ways in which tourism can, in turn, enhance and consolidate place identities. Fifth, they illustrate the role of multiple stakeholders in the development of urban tourism, and the need to engage with these stakeholders in order to ensure success and competitiveness. Overall, it is our hope that the articles in this special edition will throw light on the ways in which tourism unfolds in a post-communist context, and stimulate more research into the specific characteristics of contemporary urban tourism in Central and Eastern Europe.

\section{Acknowledgements}

We would like to bring special thanks to Ronan Paddison and Ryan Powell for their feedback on the selection of the articles in this special issue. All the articles of this special edition were presented at the international conference entitled 'Building Urban Tourism through Place Making and Urban Regeneration in Central and Eastern European Countries' held in Timisoara in 19-20 May 2017.

\footnotetext{
${ }^{1} \mathrm{U}$. Sailer-Fliege, 'Characteristics of post-socialist urban transformation in East Central Europe', Geojournal, 49, 1999, pp 7-16.

${ }^{2} \mathrm{H}$. van der Wusten, 'Dictators and their capital cities: Moscow and Berlin in the 1930s', Geojournal, 52 (2000), pp339-344.

${ }^{3} \mathrm{~S}$. Voiculescu, and I.S. Jucu, 'Producing urban industrial derelict places: The case of the Solventul petrochemical plant in Timişoara', European Urban and Regional Studies Vol. 23(4) 2016, pp.765 781; See also I. S. Jucu, 'Romanian post-socialist industrial restructuring at the local scale: evidence of simultaneous processes of de-/reindustrialization in the Lugoj municipality of Romania'. Journal of Balkan and Near Eastern Studies, 17(4), 2015, pp. 408-426.

${ }^{4} \mathrm{D}$. Harvey, 'From Managerialism to Entrepreneurialism: The transformation in urban governance in late capitalism', Geografiska Annaler: Series B, Human Geography, 71(1), 1989, pp.3-17.

${ }^{5}$ L. Sykora, 'Post-socialist cities', in R. Kitchin and N. Thrift (eds) International Encyclopedia of Human Geography, 8, Elsevier, Oxford, 2009, pp. 387-395; K. Stanilov, 'Democracy, markets, and public space in the transitional societies of Central and Eastern Europe', in K. Stanilov (ed) The PostSocialist City, Springer, Dordrecht, 2008, pp. 269-283.

${ }^{6}$ S. Voiculescu, 'Gentrification and urban renewal', in S. Voiculescu (ed.) The Romanian Postsocialist City: Urban Renewal and Gentrification, Editura Universitătii de Vest, 2009, pp 85-142.

7 D. Light and C. Young, 'Urban space, political identity and the unwanted legacies of state socialism: Bucharest's problematic Centru Civic in the post-socialist era', Nationalities Papers, Vol. 41, No. 4, 2013, pp. 515-535

${ }^{8}$ D.R Hall, 'Evolutionary pattern of tourism development in Eastern Europe and the Soviet Union', in D.R. Hall (ed.) Tourism and Economic Development in Eastern Europe and the Soviet Union, London, Belhaven, 1991, pp.79-115.

9 D.R. Hall, 'Tourism change in Central and Eastern Europe', in A. Montanari and A. Williams (eds.) European Tourism: Regions, Spaces and Restructuring, Chichester, Wiley, 1995, pp.221-244. 10 United Nations World Tourism Organisation, UNWTO Tourism Highlights: 2017 Edition, Madrid, UNWTO; UNWTO, UNWTO International Tourism Highlights: 2019 Edition, Madrid, UNWTO.

${ }^{11}$ H.L. Hughes and D. Allen, 'Central and Eastern Europe and EU accession 2004: Views of the impact on tourism', Tourism and Hospitality Research 9, 2009, pp.185-198.

12 UNWTO 2017, op cit.

${ }^{13}$ V. Dumbrovská and D Fialová, 'Tourist intensity in capital cities of Central Europe: Comparative analysis of tourism in Prague, Vienna and Budapest', Czech Journal of Tourism 3(1), 2014, pp.5-26.
} 
${ }^{14} \mathrm{~T}$. Coles, 'Urban tourism, place promotion and economic restructuring: The case of post-socialist Leipzig', Tourism Gographies, 5(2), 2003, pp.190-219.

15 W. Cudny, T. Michalski, and R. Rouba (eds.), Tourism and the Transformation of Large Cities in the Post-Communist Countries of Central and Eastern Europe, Łódź: Łódzkie Towarzystwo Naukowe,

2012

${ }^{16}$ D. Turnock, The Human Geography of East Central Europe, London, Routledge, 2003.

${ }_{17}$ A. Williams and V. Balaz, Tourism in Transition: Economic Change in Central Europe, London, I.B. Tauris, 2000.

${ }^{18}$ Turnock, op cit.

${ }^{19} \mathrm{P}$. Niewiadomski, 'The expansion of international hotel groups into Central and Eastern Europe after 1989 - strategic couplings and local responses', in D.Hall (ed.) Tourism and Geopolitics: Issues and Concepts from Central and Eastern Europe, Wallingford, CABI, 2017 pp. 115-126.

20 Dumbrovská and Fialová op cit.

${ }^{21}$ Turnock, op cit.

${ }^{22} \mathrm{C}$. Young and S. Kazcmarek, 'Changing the perception of the post-socialist city: Place promotion and Imagery in Łódź, Poland', Geographical Journal, 165(2), 1999, 183-191.

${ }^{23}$ Vesalon, L. and Creţan, R., "'Little Vienna" or "European avant-garde city"? Branding narratives in a Romanian city, Journal of Urban and Regional Analysis, 11(1), 2019, pp. 19-34.

24 J. Urry and J. Larsen, The Tourist Gaze 3.0, London, Sage, 2011.

${ }^{25}$ M. Robinson and M. Novelli, 'Niche tourism: An introduction', in M. Novelli (ed.) Niche Tourism: Contemporary Issues, Trends and Cases', Amsterdam, Elsevier, 2003, p. 7.

${ }^{26}$ D. Light, C. Young, and M. Czepczyński, 'Heritage Tourism in Central and Eastern Europe', in D. J. Timothy and G.P. Nyaupane (eds) Cultural Heritage and Tourism in the Developing World,

Routledge, London, 2009, pp 224-245.

${ }^{27}$ Light, Young and Czepczyńsk, op cit.

${ }^{28}$ R. Hammersley and T. Westlake, 'Urban heritage in the Czech Republic', in G.J. Ashworth and P.J.

Larkham (eds.) Building a New Heritage: Tourism, Culture and Identity in the New Europe,

Routledge, London, 1994, pp.178-200.

${ }^{29}$ T. Borén and M. Gentile, 'Metropolitan processes in post-communist states: An introduction',

Geografiska Annaler: Series B, Human Geography 89 (2), 2007, pp. 95-110.

${ }^{30} \mathrm{~F}$. Simpson, 'Tourism impact in the historic centre of Prague: resident and visitor perceptions of the historic built environment', Geographical Journal 165 (2), 1999, pp 173-183.

31 Dumbrovská and Fialová op cit.

${ }^{32}$ D. Light, 'Gazing on communism: heritage tourism and post-communist identities in Germany, Hungary and Romania', Tourism Geographies 2(2), 2000, pp.157-176

${ }^{33}$ J.Kivela and J.C. Crotts, 'Tourism and gastronomy: Gastronomy's influence on how tourists experience a destination', Journal of Hospitality and Tourism Research, 30(3), 2006, pp354-377.

${ }^{34} \mathrm{G}$. Richards, 'Gastronomy: An essential ingredient in tourism production and consumption?', in A-M Hjalager and G. Richards (eds.) Tourism and Gastronomy, London, Routledge, 2002, pp.1-20.

${ }^{35}$ L.Matoga and A. Pawłowska, 'Off-the-beaten-track tourism: A new trend in the tourism development in historical European cities. A case study of the city of Krakow, Poland', Current Issues in Tourism (published online).

${ }^{36}$ D. MacCannell, The Tourist: A New Theory of the Leisure Class, New York, Schocklen, 1976.

${ }^{37} \mathrm{H}$. Füller and B. Michel, "Stop being a tourist!': New dynamics of urban tourism in Berlin-

Kreuzberg', International Journal of Urban and Regional Research, 38(4), 2014, pp.1304-18.

38 J.Dickenson and L. Lumsdon, Slow Travel and Tourism, London, Earthscan, 2010.

${ }^{39}$ R. Pawlusiński and M. Kubal, 'A new take on an old structure? Creative and slow tourism in Krakow (Poland)', Journal of Tourism and Cultural Change, 16(3), 2018, pp. 265-285.

${ }^{40} \mathrm{G}$. Richards, 'Creativity and tourism in the city', Current Issues in Tourism, 17(2), 2014, pp.119-114.

${ }^{41}$ E. Pijet-Migoń, 'The geopolitics of Low-cost Carriers in Central and Eastern Europe', in D. Hall (ed.) Tourism and Geopolitics: Issues and Concepts from Central and Eastern Europe, Wallingford, CABI, 2017, pp. 307-321.

42 F. Dobruszkes, 'New Europe, new low-cost air services', Journal of Transport Geography, 17(6), 2009, pp. 423-432.

43 Pijet-Migoń, op cit.

${ }^{44}$ A Leask, A.Fyall, and P. Barron, 'Generation Y: An agenda for future visitor attraction research', International Journal of Tourism Research, 16(5), 2014, pp. 462-471. 
45 T. Thurnell-Read, 'Tourism place and space: British stag tourism in Poland', Annals of Tourism Research, 39(2), 2012, pp.801-819.

${ }^{46}$ G.Zervas, D. Proserpio and J.W. Byers, 'The rise of the sharing economy: Estimating the impact of Airbnb on the hotel industry', Journal of Marketing Research, 54(5), 2017, pp. 687-705

47 Ibid.

${ }^{48}$ K.Gyódi, 'Airbnb and the hotel industry in Warsaw: An example of the sharing economy?', Central European Economic Journal, 2(49), 2017, pp. 23-34.

${ }^{49}$ Zervas, Proserpio and Byers, op cit.

${ }^{50}$ Gyódi op cit.

${ }^{51}$ A.Smith, Events and Urban Regeneration: The Strategic Use of Events to Revitalise Cities, Abingdon, Routledge, 2012.

52 D.R Hall, 'Tourism opportunities in Eastern Europe and the Soviet Union', in D.R. Hall (ed.) Tourism and Economic Development in Eastern Europe and the Soviet Union, London, Belhaven, 1991, pp.29-48. 